\title{
THE INFLUENCE OF SHOOT HARVESTING ON THE AGE STRUCTURE OF CONVALLARIA MAJALIS L. POPULATIONS
}

\author{
IGOR KOSIŃSKI \\ Department of Biology and Botany \\ Medical University of Gdansk \\ Al. gen. J. Hallera 107, 80-416 Gdansk, Poland
}

(Recived: March 5, 2002. Accepted: January 16, 2003)

\begin{abstract}
This paper presents the structure of developmental stages and the age structure of Convallaria majalis L. populations. The investigation material consisted of individuals and modules from populations in Betulo-Quercetum, Fago-Quercetum, Melico-Fagetum and Tilio-Carpinetum, in which the leaves and inflorescence of C. majalis were cut annually over a period of three years.

Fifty percent of the C. majalis regional population consisted of mature modules, $20 \%$ of juvenile modules, $25 \%$ of senile modules and a very small percentage of generative modules. In populations of Fago-Quercetum there are four times more senile modules than juvenile modules, while in Melico-Fagetum the percentage of juvenile modules is four times more numerous than the percentage of senile modules. The average age of modules is $4.7 \pm 3.8$ years. Three year old individuals dominate in the population, while 10 year or older individuals are very rare.

In the population disturbed by the three raw material collections, the percentage of juvenile modules was decreased by $50 \%$ and the percentage of generative modules was nonexistent. As a result, the average module age is higher than in the undisturbed population. Cutting leaves and inflorescence is an important factor in limiting the recruitment of juvenile modules. The growth of individuals in the disturbed population occurs among older modules, which were able to reproduce before the disturbance occurred. Young individuals (three to four years old) are less numerous in the disturbed population, and the majority of individuals are three to six years old.
\end{abstract}

KEY WORDS: Convallaria majalis L., medicinal plant, age structure, shoot cutting.

\section{INTRODUCTION}

Investigations of the age structure in perennial plant populations have been carried out frequently (Rabotnov 1969; Symonides 1979; Stasiak 1994; Czarnecka 1996; Falińska 1997; Stoll et al. 1998). The dependence of age structure on the dynamics of population abundance and the size structure of individuals has been described. Investigations of age structure and its dynamics allow the fate of the population to be forecasted. The age structure can be modified by increased density, food resources, interspecies competition and interactions between individuals (Falińska and Żyromska-Rudzka 1986). There is relatively little information regarding the impact of destructive factors, such as grazing or cutting the aboveground organs, on the age structure of the population (Kaźmierczakowa and Rams 1984; Nault and Gagnon 1993; del Barrio et al. 1999).

C. majalis is a medicinal plant which contains cardenolides (Paris 1963). In Poland, it is harvested from both plantations and naturally occurring populations. For this reason, this species is under partial preservation. It has been proven through simulated raw material collection, that ha- rvesting $C$. majalis negatively impacts the density and crops in subsequent years, the cardenolide content, size and fertility (Kosiński 1996, 2001).

The aim of the study was to determine the type and direction of changes in the age structure of the Convallaria majalis population when subjected to long-term, simulated raw material collection for pharmaceutical purposes.

\section{MATERIAL AND METHODS}

Convallaria majalis is characterized by iterative growth. The basic structural element of the $C$. majalis individual consists of the underground (a rooted rhizome) and aboveground parts (leaves and inflorescence), further referred to as the shoot. As such, the structural unit of an individual is the module (Harper 1977), i.e. a repeatable element in the architecture of the individual.

An individual may be one or multi-module in character, with the latter referred to as a polycormone (Penzes 1960). The particular parts (modules) of individuals are different ages and represent different developmental stages. The increase, decrease or stabilization of the contribution of 


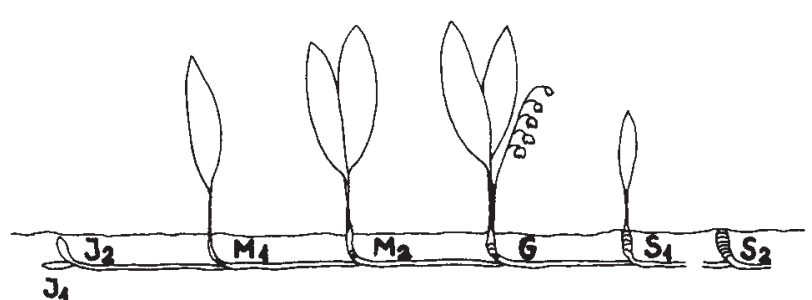

Fig. 1. Development diagram of Convallaria majalis modules: J1 - early juvenile; J2 - juvenile; M1 - early mature; M2 - mature; G - generative; S1 - subsenile; S2 - senile.

a particular developmental stage indicates, in this case, structural changes in populations.

The following seven developmental stages were determined in the development of the module (Fig. 1): early juvenile $\left(\mathrm{J}_{1}\right)$, juvenile $\left(\mathrm{J}_{2}\right)$, early mature $\left(\mathrm{M}_{1}\right)$, mature $\left(\mathrm{M}_{2}\right)$, generative $(G)$, subsenile $\left(S_{1}\right)$, senile $\left(S_{2}\right)$.

The early juvenile stage $\left(\mathrm{J}_{1}\right)$ lasts for about six months, and it originates as a renewal bud in the joint of the older module. It develops entirely in the soil and it is completely covered by scales.

In the following year, the early juvenile module changes into the juvenile stage $\left(\mathrm{J}_{2}\right)$, which is created due to the intensive increase of rhizome length. This is when the first adventitious roots develop, but the aboveground organs have still not appeared. This stage lasts for one year, occasionally it may last for even the two following years. In this stage of development, the most intensive production of modules occurs, since almost half of them $(40 \%)$ create new modules (early juvenile).

The early mature module $\left(\mathrm{M}_{1}\right)$ has a fully-formed rhizome and it is the first developmental stage with aboveground organs in the form of one $(77 \%)$ or two leaves. This stage lasts for one year and it may be identified by the lack of a leaf scars on the orthotropic part of the rhizome. The early mature modules reproduce less frequently than do those of the juvenile, since new modules are created by only a third of them $(30 \%)$.

The mature module $\left(\mathrm{M}_{2}\right)$ most often has two leaves or sometimes it has three. The orthotropic part of rhizome has a greater diameter than in the early mature stage and it is covered by a base of foliage leaves from previous years. After three years, these modules turns into the subsequent developmental stage, i.e. generative, however, there are some which never bloom and move directly into the subsenile stage.

The module usually reaches the generative stage $(\mathrm{G})$ in the sixth year of development. At this point, the module usually has inflorescence and most often two leaves. It is a repetitive stage. The results of the investigation indicate that the generative module can create inflorescence for twenty years with breaks of a year or two. Nearly thirty percent of the generative modules in the population, i.e. a similar number to the mature modules, develops by creating new modules.

The subsenile module $\left(\mathrm{S}_{1}\right)$ has a clearly reduced assimilation surface usually consisting of one very small leaf. The plagiotropic part of the rhizome dies leaving only its youngest (orthotropic) part. In the following year this module moves to the senile stage, $\mathrm{S}_{2}$, which has no leaves.

The field experiments were carried out from 1992 to 1996 in four coenopopulations of $C$. majalis located in the region of Gdańsk, northern Poland. Forest communities with numerous $C$. majalis coenopopulations were chosen for the investigations: Betulo-Quercetum roboris $\mathrm{R}$. Tx. 1937 (in short: B-Q), Fago-Quercetum petraeae R. Tx. 1955 (F-Q), Melico-Fagetum Lohm. ap. Seibert 1954 (M-F) and Tilio-Carpinetum Tracz. 1962 (T-C). The area of the coenopopulation is within the borders of the phytocoenosis (Rabotnov 1985a). All the coenopopulations in study area compose a regional population.

The least light (11\%) penetrates to the field layer in $\mathrm{Fa}$ go-Quercetum petraeae and a lot of light (70\%) reaches the herb layer in Tilio-Carpinetum. Rather moist and very acid soil $(\mathrm{pH}=3.5)$, rich in organic matter was in Betulo-Quercetum roboris. The herb layer was dominated (apart from C. majalis) by: Maianthemum bifolium and Trientalis europaea in B-Q, Vaccinium myrtillus and Oxalis acetosella in F-Q, Maianthemum bifolium in M-F and Anemone nemorosa, Stellaria holostea in T-C.

Four pairs of plots (experimental and control) of a total area of $16 \mathrm{~m}^{2}$ were used in the age structure investigations. Cutting the aboveground organs of $C$. majalis was a simulation of collecting raw material for the pharmaceutical industry. The leaves and inflorescence were cut once a year (in May) while the plants were in bloom over a period of four consecutive years in all of the experimental plots. Material for the investigations was simultaneously collected from control and experimental plots after the third cut of aboveground organs of $C$. majalis.

The age of modules was determined using two methods, direct and indirect; the first method involved determining the absolute age, expressed in years, while the second involved the separation of development stages, in accordance with Rabotnov (1969).

The absolute module age was determined based on preserved scars left by the rhizome scales and by the foliage leaves. Scars after scales are closer together than are those of the leaves; by counting the pairs of these two types of scars it is possible to determine the module age precisely (Fig. 2). These investigations were carried out on 1.100 modules of 260 individuals. It was assumed that the individual is as old (relative age) as the oldest module in it. The features of the developmental stages were determined based on 40 modules which were investigated from the appearance of the renewal bud to dying.

At the begining of study population density in experimental and control plots varied from $143.4 \pm 64.0$ shoots $\cdot \mathrm{m}^{-2}$ in Betulo-Quercetum to $33.8 \pm 18.2$ shoots $\cdot \mathrm{m}^{-2}$ in Fago-Quercetum. In the last year of experiment population density in control plots did not change significantly. However, in experimental plots density was significantly decreased to $100.0 \pm 37.3$ shoots $\cdot \mathrm{m}^{-2}$ in Betulo-Quercetum and 13.3 \pm 8.6 shoots $\cdot \mathrm{m}^{-2}$ in Fago-Quercetum.

Statistical processing entailed computation the arithmetical mean $(\overline{\mathrm{X}})$, standard deviation (S.D.), modal (Mo), and the variability coefficient according to the following formula: $\mathrm{CV}=\mathrm{S} . \mathrm{D} . \cdot \overline{\mathrm{X}}^{-1}$. The compliance of the empiric feature distribution with the normal distribution was verified using the $\chi^{2}$ test (Oktaba 1980; Łomnicki 1995). The significance of the differences between the features was done using the variance analysis method (one way ANOVA) and with the t-Student test (Oktaba 1980). The hypothesis regarding the significance of differences between the arithmetical means and the significance of correlations and re- 


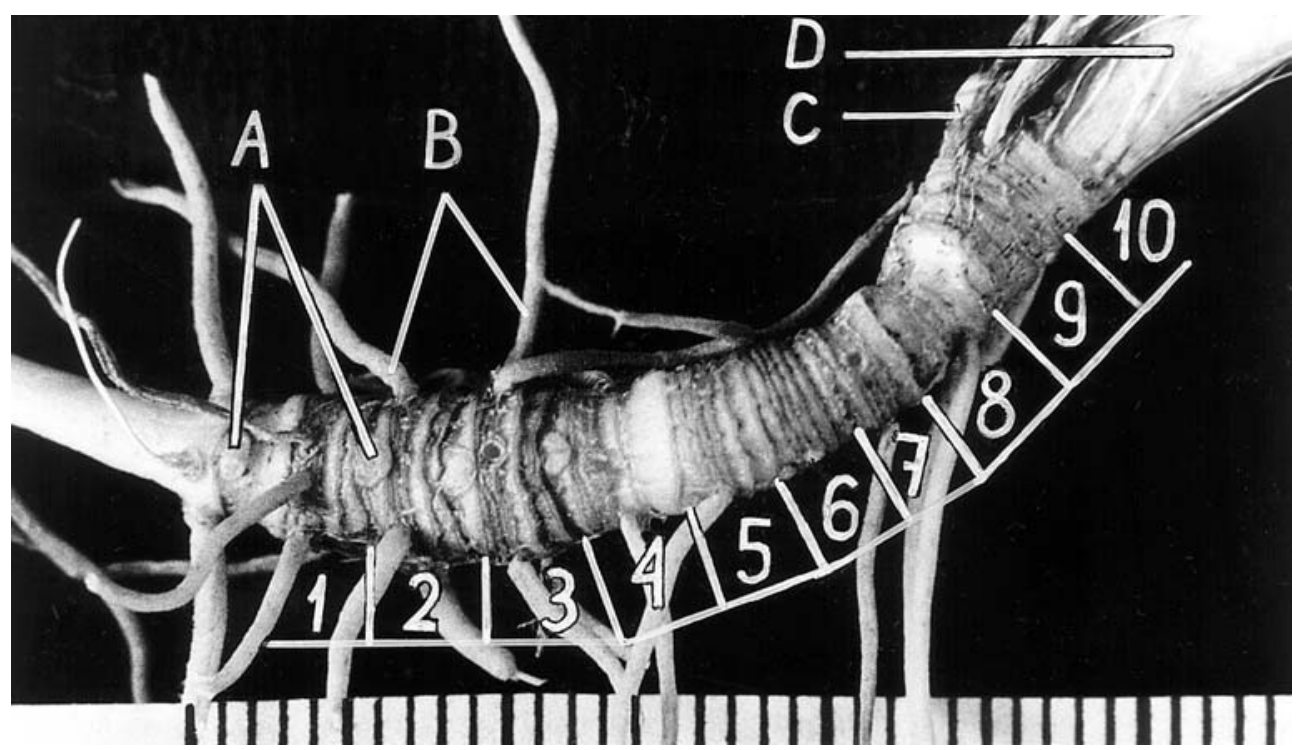

Fig. 2. Morphology of the top of the generative module rhizome: 1 10 - annual-increment segment; A - dormant buds; B - adventitious roots; C - base of the inflorescence; D - reneval bud. Millimetre scale at the bottom.

gressions were tested using the variance analysis method and the $\mathrm{F}$ coefficient. The statistical considerations were done at an error risk level of $\alpha=0.05$ (Oktaba 1980).

\section{RESULTS}

\section{AGE STRUCTURE IN THE UNDISTURBED POPULATION}

\section{Structure of development stages}

Fifty-one percent of the regional population consists of mature modules, $20 \%$ of juvenile modules, $26 \%$ of senile modules and very few (3\%) generative modules. Coenopopulations vary in their numbers of juvenile, subsenile and senile modules, e.g. there are three times more old modules than young ones in Betulo-Quercetum and four times more - in Fago-Quercetum. Since with age the probability of individual fragmentation increases, especially of its rhizome, this is the reason why the polycormones consist of a small number of modules in B-Q and F-Q. There is a lack of statistically significant differences in the structure of developmental stages in both coenopopulations.

The situation which occurs in the coenopopulations of Melico-Fagetum and Tilio-Carpinetum is different. The percentage of young modules is four times more numerous than those of the old modules in Melico-Fagetum and two times more - in Tilio-Carpinetum. Almost every third module is juvenile, and thus the process of renewal is more intense than withering and fragmentation.

\section{Age of modules}

In the regional population the arithmetical mean of module ages is $4.7 \pm 3.8$ years, and it is strongly variable $(\mathrm{CV}=$ 0.81 ; Table 1). The distribution is a single module type feature and is positively skewed; thus, there are more young modules in polycormones than it appears from the normal distribution of this feature (Fig. 3). The module can reach the age of 22 , however, much younger modules, i.e. several years old, dominate in the population.

In Betulo-Quercetum the arithmetical mean of module ages is $5.1 \pm 3.1$ years (Table 1) while the maximum value of this feature is 14 years. Here, modules do not attain such advanced ages as do those in the coenopopulations of F$\mathrm{Q}$ and M-F. The distribution of this feature indicates that
TABLE 1. Modules age in control (contr.) and experimental (exp.) plots.

\begin{tabular}{|c|c|c|c|c|c|}
\hline Population: & $\mathrm{n}$ & $\overline{\mathrm{X}} \pm$ s.d. & $\min .-\max$. & Mo & $\mathrm{CV}$ \\
\hline \multicolumn{6}{|l|}{ Regional } \\
\hline (contr.) & 677 & $4.7 \pm 3.8$ & $1-22$ & 1 & 0.81 \\
\hline (exp.) & 424 & $7.0 \pm 4.3$ & $1-26$ & - & 0.61 \\
\hline \multicolumn{6}{|c|}{ Betulo-Quercetum } \\
\hline (contr.) & 289 & $5.1 \pm 3.1$ & $1-14$ & 4 & 0.61 \\
\hline (exp.) & 103 & $7.1 \pm 2.9$ & $1-15$ & 5 & 0.41 \\
\hline \multicolumn{6}{|c|}{ Fago-Quercetum } \\
\hline (contr.) & 120 & $7.1 \pm 5.1$ & $1-21$ & 4 & 0.72 \\
\hline (exp.) & 111 & $9.4 \pm 5.6$ & $1-26$ & - & 0.60 \\
\hline \multicolumn{6}{|c|}{ Melico-Fagetum } \\
\hline (contr.) & 206 & $2.9 \pm 2.9$ & $1-22$ & 1 & 1.00 \\
\hline (exp.) & 145 & $5.3 \pm 3.6$ & $1-17$ & 1 & 0.68 \\
\hline \multicolumn{6}{|c|}{ Tilio-Carpinetum } \\
\hline (contr.) & 62 & $4.0 \pm 3.2$ & $1-11$ & 1 & 0.80 \\
\hline (exp.) & 65 & $6.1 \pm 2.9$ & $1-14$ & 6 & 0.48 \\
\hline
\end{tabular}

the greatest number of modules are four years old. Besides, the quantitative contribution of one, two, three and four year old modules is rather even, which may indicate the higher survival rate of young developmental stages in this coenopopulation than in others.

In Fago-Quercetum the arithmetical mean of module ages is $7.1 \pm 5.1$ years, and the four year old module is the most common, as was the case in B-Q (Table 1). The quantitative contribution of young modules (one to four year olds) is lower, while it is four times greater for modules over 10 years old than in the B-Q. The arithmetical mean of module ages is significantly higher than that in other coenopopulations $(p<0.001)$, which indicates the poor renewal of polycormones and strong fragmentation.

In Melico-Fagetum the arithmetical mean of module ages was 2.9 \pm 2.9 years (Table 1 ). The distribution of this feature is positively skewed. One year old modules are the most numerous, while there were $60 \%$ fewer two year old modules and modules over six years old comprised only a slight percentage of the population. The average module age is significantly lower in comparison with other coenopopulations $(\mathrm{p}<0.01)$.

In Tilio-Carpinetum the arithmetical mean of module age is $4.0 \pm 3.2$ years, and their age oscillates between 1 and 11 years, which is similar to $B-Q, p<0.05$ (Table 1 ). The di- 


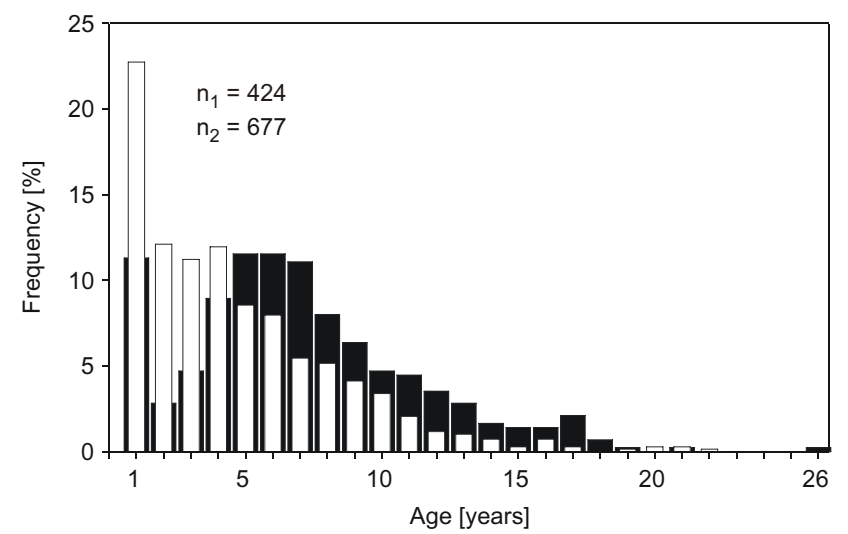

Fig. 3. Module age distribution in experimental (ם) and control ( $\square$ ) plots; $\mathrm{n}_{1}-$ number of modules in experimental plots, $\mathrm{n}_{2}-$ in control plots.

stribution of this single module type feature is positively skewed and indicates the domination of young rhizomes.

\section{Relative age of individuals}

The arithmetical mean of individual relative age in the population is $7.3 \pm 4.3$ years, and it is a rather variable feature $(\mathrm{CV}=0.59$; Table 2$)$. The distribution of polycormone age is positively skewed (Fig. 4). It indicates that young individuals dominate the population (three to four year olds), the percentage of older individuals (five to eight year olds) is relatively high and the percentage of the oldest individuals (> 10 years old) is small. Such an age distribution of polycormones in the population is yet another confirmation of very intense disintegration processes. They originate in three year old polycormones and intensify with age.

In Betulo-Quercetum the arithmetical mean of polycormone age is $5.5 \pm 2.8$ years, and it is relatively variable $(\mathrm{CV}$ $=0.51)$ and significantly lower $(\mathrm{p}<0.001)$ than in the case of the regional population (Table 2). Every sixth individual is three years old, and the older individuals (four to eight years old) are rather numerous. Thus, polycormone age distribution is similar to the entire regional population.

In Fago-Quercetum polycormones are 8.7 \pm 5.5 years old; they are older than those in B-Q $(\mathrm{p}<0.001)$ and the entire regional population. The distribution of this feature indicates the rather high and relatively even contribution of three to 16 year old polycormones. In Melico-Fagetum individu-

TABLE 2. Individual age in control (contr.) and experimental (exp.) plots.

\begin{tabular}{lccccc}
\hline Population: & $\mathrm{n}$ & $\overline{\mathrm{X}} \pm$ s.d. & min.-max. & Mo & $\mathrm{CV}$ \\
\hline $\begin{array}{l}\text { Regional } \\
\quad \text { (contr.) }\end{array}$ & 148 & $7.3 \pm 4.3$ & $3-21$ & 3 & 0.59 \\
$\quad$ (exp.) & 112 & $7.3 \pm 3.7$ & $3-25$ & 6 & 0.51 \\
$\begin{array}{l}\text { Betulo-Quercetum } \\
\quad \text { (contr.) }\end{array}$ & 70 & $5.5 \pm 2.8$ & $3-14$ & 3 & 0.51 \\
$\quad($ exp.) & 28 & $6.0 \pm 2.4$ & $3-12$ & 4 & 0.40 \\
$\begin{array}{l}\text { Fago-Quercetum } \\
\quad \text { (contr.) }\end{array}$ & 51 & $8.7 \pm 5.5$ & $3-21$ & - & 0.63 \\
$\quad($ exp.) & 34 & $8.1 \pm 5.2$ & $3-25$ & 3 & 0.64 \\
$\begin{array}{l}\text { Melico-Fagetum } \\
\quad \text { (contr.) }\end{array}$ & 17 & $6.5 \pm 4.8$ & $3-21$ & 4 & 0.74 \\
$\quad$ (exp.) & 32 & $7.1 \pm 3.2$ & $3-16$ & 6 & 0.45 \\
$\begin{array}{l}\text { Tilio-Carpinetum } \\
\quad \text { (contr.) }\end{array}$ & 10 & $7.7 \pm 2.0$ & $5-11$ & - & 0.26 \\
$\quad$ (exp.) & 18 & $6.4 \pm 3.1$ & $3-13$ & 6 & 0.48 \\
\hline
\end{tabular}

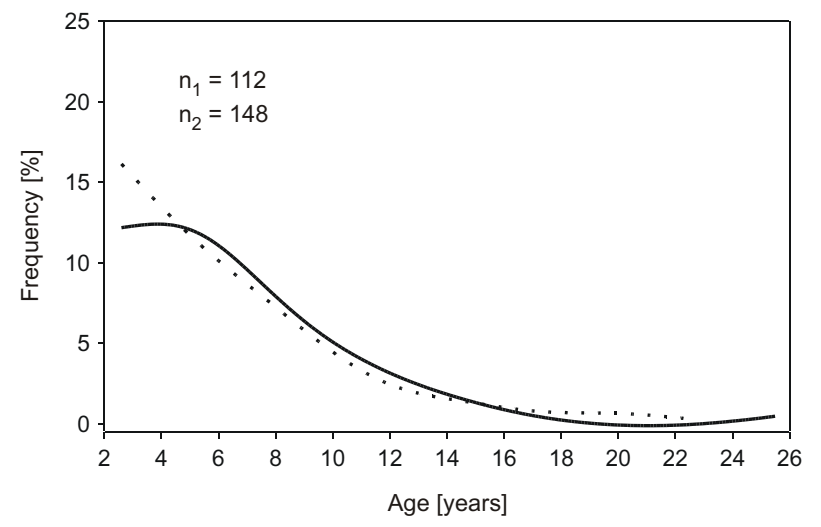

Fig. 4. Individuals age distribution in experimental (-) and control (- - plots; $\mathrm{n}_{1}-$ number of modules in experimental plots, $\mathrm{n}_{2}-$ in control plots.

als are $6.5 \pm 4.8$ years old, while in Tilio-Carpinetum they are $7.7 \pm 2.0$ years old (Table 2), i.e. they are younger than in F-Q, however, the differences are statistically not significant.

\section{AGE STRUCTURE IN THE DISTURBED POPULATION}

\section{Structure of developmental stages}

After raw material had been collected three times, $9 \%$ of the modules in the population were juvenile, $57 \%$ were mature and $34 \%$ were senile. Therefore, the mature module percentage did not change, while the percentage of senile modules increased (from 26 to $34 \%$ ), and the percentages of both the juvenile and generative modules decreased radically, from 20 to $9 \%$ and to zero, respectively. Thus, the fundamental change in the disturbed population regards the quantitative contribution of stages which determine the level of reproduction and recruitment of young modules.

There are at least several interpretations for the decrease in the juvenile module contribution to the population. One of them is the increased period of the duration of the juvenile stage in the population with a simultaneous inhibition of the creation of new modules. The early juvenile stage $\left(\mathrm{J}_{1}\right)$ changes into the juvenile stage $\left(\mathrm{J}_{2}\right)$ as a result of intensive rhizome plagiotropic development (length) and it lasts from six months to two years. During this time, few juvenile modules were probably created in the polycormones, and some of the existing modules changed into mature ones. This interpretation is confirmed by the results of investigations of modules in coenopopulation of B-Q (Kosiński 1998); the average module length increased during the experiment which may be explained by the decrease of the tempo of juvenile module development without inhibiting their further length increase.

In the undisturbed population, the young modules originated mainly on juvenile modules, while in the disturbed population they were on the mature modules. Since the main "effort" of mature modules is directed towards the creation of aboveground organs (leaves), the creation of new modules is weaker; this may also explain the decrease of their percentage of the disturbed population.

Increased numbers of senile stages in the population is a natural consequence of the aging of mature modules; this was manifested in every experimental plot by the enhanced fragmentation of rhizomes. The modules created in this 
way had all the features of the senile stage, i.e. very short and withering rhizome, which produced rare, but seriously deformed, new juvenile modules.

The contribution of the developmental stages in each disturbed coenopopulation was similar, and although significant differences in numbers were confirmed among some of them, the trends of changes were always the same. Senile modules were two to eight times more numerous than the juvenile modules in every coenopopulation, which clearly indicates the rapid process of rhizome aging. After three raw material collections, the polycormones are short and they have simplified architecture, i.e. they have a linear form with a clear tendency to reduced side ramification, and their aboveground parts have smaller assimilation surfaces (Kosiński 2001).

\section{Age of modules}

Three raw material collections caused several fundamental changes in the age structure. The arithmetical mean of module ages is significantly higher $(7.0 \pm 4.3$ years; $p<0.001$; Table 1), mainly due to the lower percentage of young modules, i.e. two to four year olds, which developed during the experiment (Fig. 3). Therefore, shoot cutting as a disturbance is significant in limiting the recruitment of juvenile modules and the development of polycormones.

In polycormones from disturbed populations, the percentage of juvenile modules is many times lower than that of the early juvenile modules, which may suggest the arrest of the further development of the latter. Additionally, in the disturbed population young modules are created on modules aged $4.7 \pm 2.7$ years old ( $\mathrm{Mo}=5$ years), while in the undisturbed population they occur on much younger modules, i.e. $1.3 \pm 0.5$ years old $(\mathrm{Mo}=1$ year; $\mathrm{p}<0.001)$. The development of polycormones in the disturbed population is based on these modules, which were able to reproduce before the occurrence of the disturbance.

In Betulo-Quercetum the arithmetical mean of module ages in polycormones is $7.1 \pm 2.9$ years. Two, three and four year old modules are six, three and two times less numerous than in the undisturbed population, respectively. Modules older than five are on average two times more numerous. The structure of changes of module age in undisturbed populations and those after the experiment is similar to the other coenopopulations, i.e. after the triple shoot cutting, the age of modules is higher.

In Fago-Quercetum, similarly to the B-Q population, the annual collection of raw material over three years, leads to the attenuation of polycormone development, and further to the increase of the arithmetical mean of the age of its modules $(9.4 \pm 5.6$ years versus $7.1 \pm 5.1$ years; $\mathrm{p}<0.001$; Table 1$)$.

In Melico-Fagetum the arithmetical mean of module ages is $5.3 \pm 3.6$ years. The type and tendency of changes in the age structure of modules in polycormones are, in this case, the same as in other coenopopulations, including coenopopulation in Tilio-Carpinetum (Table 1).

\section{Relative age of individuals}

In the population that was disturbed by shoot cutting three times, young individuals (three to four years old) are less numerous, and three to six year old individuals are most numerous (Fig. 4). Three year old polycormones dominate in the undisturbed population, while six year old polycormones dominate in the disturbed population (Table 2).
In the disturbed coenopopulation in B-Q the arithmetic mean of individual relative age is $6.0 \pm 2.4$ years, in F-Q $8.1 \pm 5.2$, in M-F 7.1 \pm 3.2 , while in $\mathrm{T}-\mathrm{C}$ it was $6.4 \pm 3.1$ (Table 2). The comparison of the average age of polycormones before raw material collection and after three collections, indicates that the age of these individuals does not vary on a statistically significant level $(7.3 \pm 4.3$ years versus $7.3 \pm 3.7$ years).

The age distribution in a population consisting of individuals that grow iteratively in terms of diagnostics is not very significant. The distribution of module ages or even developmental stages are far more precise indicators of change.

\section{DISCUSSION}

According to Grime (1979), three types of selection decide which strategy is employed: competition (C), stress (S) and disturbance (R). In this system, $C$. majalis is a C-S strategy species that is used to moderately intense stress and weak environmental disturbances. A similar strategy is apparent for Maianthemum bifolium (Czarnecka 1986) and Mercurialis perennis (Grime 1979). C. majalis makes survival organs in the form of renewal buds and seeds (strategy features C), has a long-term underground system which collects products of photosynthesis (strategy S), and is also characterized by a small biomass effort on generative reproduction (a common feature of both $\mathrm{C}$ and $\mathrm{S}$ ).

The basic adaptive strategy of multi-module perennials is their longevity which they achieve by the renewal of vegetative structures (Harper and Ogden 1970; Watkinson and White 1985). The creation of new shoots leads to a decrease in the risk of individual death. Thanks to this ability, a $C$. majalis clone can exist in the same place for a period of even 670 years (Oinonen 1969).

In a $C$. majalis population, despite the natural tendency of individuals to grow and create a complex, multi-module architecture, the construction of the majority of individuals is very simple (Kosiński 1998). Based on the material collected, it is difficult to stage definitively why the majority of individuals in the $C$. majalis population consists of only one or two modules and why a large polycormone is not always the final pattern in the architecture of a mature individual. The results obtained indicate that in coenopopulations which only reproduce vegetatively (in Melico-Fagetum and Tilio-Carpinetum), polycormones have more complex architecture than in the coenopopulations that reproduce generatively (in Betulo-Quercetum and Fago-Quercetum). The simpler structure of a majority of individuals may also result from intraclone density regulation, as suggested by Harper (1985), when overlapping zones of resource depletion of particular modules causes the necrosis of old modules. This interpretation is valid for the undisturbed population only in Betulo-Quercetum where the density and numbers of individuals with one and two modules was the greatest. In my opinion, the magnitude of the percentage of small module percentages is also affected by the age distribution, and the older the population the greater the number of individuals with a simple structure, for example - the undisturbed population in F-Q.

A common phenomenon of vegetative reproduction leads to the creation of new structural units (modules), which vary not only with size and habit but also with age. Harper 
(1980) sees multi-module organism growth as a demographic process. In the case of $C$. majalis, it is also a structure forming process, which, on one hand, leads to the compilation of polycormone architecture, and, on the other, to its disintegration, especially during aging.

Grazing animals damage plants, and this also influences the life span of the plant. The effects of grazing depend, among other factors, on the plant's life form (Falińska 1996). Results obtained by Krylova (1993) indicate that populations of $C$. majalis that were moderately grazed have a greater density the following year, while populations that were intensively grazed for a couple of years, become completely extinct. Results obtained by Rabotnov (1985b) indicate that grazing or cutting of some plants, e.g. Anemone fasciculata, leads to significant changes in the architecture of the individual and in the structure of the population. It was confirmed that the earlier the cut, the greater the changes in the population age distribution. Similar reactions are also observed among $C$. majalis, which may result from disturbances in the development of the individual architecture and renewal of populations caused by simulated cuts during the period of full plant development.

As a result of cutting the aboveground organs, C.majalis rhizomes produce less renewal buds, individuals regenerate weakly and have a simpler structure. After repeated shoot cutting regressive traits became visible so in order to preserve natural populations of C.majalis only single harvest should be permissible.

\section{ACKNOWLEDGEMENTS}

I am grateful to Prof. Dr hab. Józef Szmeja for his kind advice and constructive comments on a previous manuscript. I thank anonymous reviewer for valuable comments and suggestions on an earlier draft of this paper. This research has been supported by the Medical University of Gdańsk.

\section{LITERATURE CITED}

DEL BARRIO J., LUIS-CALABUIG E., TARREGA R. 1999. Vegetative response of Arctostaphylos uva-ursi to experimental cutting and burning. Plant Ecol., 145: 191-195.

CZARNECKA B. 1986. Biological properties of Majanthemum bifolium (L.) F.W. Schm. polycormones under various ecological conditions. Acta. Soc. Bot. Pol. 55: 659-678.

CZARNECKA B. 1996. Clonal organisation of populations of Asarum europaeum and Maianthemum bifolium in contrasting woodland habitats. Vegetatio, 125: 51-62.

FALIŃSKA K. 1996. Ekologia roślin. Wyd. Naukowe PWN, Warszawa (in Polish).

FALIŃSKA K. 1997. Life history variation in Cirsium palustre and its consequences for the population demography in vegetation succesion. Acta Soc. Bot. Pol. 66: 207-220.

FALIŃSKA K., ŻYROMSKA-RUDZKA H. 1986. Struktura wiekowa populacji. In: Populacje roślin i zwierząt. Andrzejewski R., Falińska K. (ed.). PWN, Warszawa, pp. 78-110 (in Polish).

GRIME J.P. 1979. Plant strategies and vegetation processes. Wiley and Sons, Chichester-New York-Brisbane- Toronto-Singapore.
HARPER J.L. 1977. population biology of plants. Academic Press, London-New York-San Francisco.

HARPER J.L. 1980. Plant demography and ecological theory. Oikos 35: 244-254

HARPER J.L. 1985. Modules, branches and the capture of resources. In: Jackson J.B.C., Buss L.W., Cook R.E. (ed.). Population biology and evolution of clonal organisms. Yale University Press, New Haven-London.

HARPER J.L., OGDEN J. 1970. The reproductive strategy of higher plants. I. The concept of strategy with special reference to Senecio vulgaris L. J. Ecol. 58: 681-698.

KAŹMIERCZAKOWA R., RAMS B. 1984. Ekologiczna analiza procesu odnawiania się kopytnika pospolitego Asarum europaeum L. po zbiorze. In: Stan zagrożenia oraz warunki zabezpieczenia naturalnych zasobów roślin leczniczych. Gawłowska J. (ed.). Studia Naturae, ser. A, 25: 67-104 (in Polish with English summary).

KOSIŃSKI I. 1996. Content of cardenolide glycosides in Convallaria majalis $\mathrm{L}$. from populations disturbed and not disturbed by cutting. Pol. Ecol. Stud. 22: 17-28.

KOSIŃSKI I. 1998. Transformacja populacji Convallaria majalis L. jako efekt pozyskiwania surowca dla przemysłu farmaceutycznego. Ph. D. Thesis, Uniwersytet Gdański (in Polish).

KOSIŃSKI I. 2001. The influence of shoot harvesting on the size and fecundity of Convallaria majalis L. Acta Soc. Bot. Pol. 70: 303-312.

KRYLOVA I.L. 1993. Convallaria majalis L. kak komponient rastitelnych soobšeestv. Rast. Res. 29: 1-10 (in Russian).

ŁOMNICKI A. 1995. Wprowadzenie do statystyki dla przyrodników. Wyd. Naukowe PWN, Warszawa (in Polish).

NAULT A., GAGNON D. 1993. Ramet demography of Allium tricoccum, a spring ephemeral, perennial forest herb. J. Ecol. 81: 101-119.

OINONEN E. 1969. The time table of vegetative spreading of the lily-of-the-valley (Convallaria majalis L.) and the wood smallreed (Calamagrostis epigeios (L.) Roth.) in Southern Finland. Acta Forest. Fenn. 97.

OKTABA W. 1980. Elementy statystyki matematycznej i metodyka doświadczalnictwa. PWN, Warszawa (in Polish).

PARIS R. 1963. The distribution of plant glycosides. In: Chemical plant taxonomy. Swain T. (ed.). Academic Press, London-New York, pp. 337-358.

PENZES A. 1960. Über die Morphologie, Dynamik und zönologische Rolle der sprosskolonienbilden - den Pflanzen (Polycormone). Fragm. Flor. Geobot. 6: 505-516.

RABOTNOV T.A. 1969. On coenopopulations of perennial herbaceous plants in natural coenoses. Vegetatio 19: 87-95.

RABOTNOV T.A. 1985a. Dynamics of plant coenotic populations. In: White J. (ed.). The population structure of vegetation. Dr. W. Junk Publishers, Dordrecht-Boston-Lancaster, pp. 121-142.

RABOTNOV T.A. 1985b. Fitocenologia. PWN, Warszawa (in Polish).

STASIAK J. 1994. Age structure of Juncus balticus Willd. coenopopulations and changes in individual's characters during primary succesion. Ekol. pol. 42: 173-205.

STOLL P., EGLI P., SCHMID B. 1998. Plant foraging and rhizome growth patterns of Solidago altissima in response to mowing and fertilizer application. J. Ecol. 86: 341-354.

SYMONIDES E. 1979. The structure and population dynamics of psammophytes on inland dunes. II. Loose-sod populations. Ekol. Pol. 27: 191-234.

WATKINSON A.R., WHITE J. 1985. Some life-history consequences of modular construction in plants. Phil. Trans. R. Soc. Lond. B 313, 31-51. 


\section{WPŁYW POZYSKIWANIA PĘDÓW \\ NA STRUKTURĘ WIEKOWĄ POPULACJI CONVALLARIA MAJALIS L.}

\section{STRESZCZENIE}

Przedstawiono strukturę stadiów rozwojowych i strukturę wiekową populacji Convallaria majalis L. Obiektem badań były osobniki i ich moduły z populacji w Betulo-Quercetum, Fago-Quercetum, Melico-Fagetum i TilioCarpinetum, w których raz w roku, przez trzy kolejne lata ścinano liście i kwiatostany C. majalis.

W regionalnej populacji $C$. majalis było $1 / 2$ modułów maturalnych, $1 / 5$ juwenilnych, 1/4 senilnych i bardzo nieliczna frakcja modułów generatywnych. W Fago-Quercetum senilnych modułów było 4-krotnie więcej niż juwenilnych, natomiast w Melico-Fagetum frakcja modułów juwenilnych była 4 razy liczniejsza niż senilnych. Średni wiek modułu wynosił 4,7 $\pm 3,8$ lat. W populacji dominowały osobniki 3-letnie, natomiast 10-letnie i starsze były nieliczne.

W populacji zaburzanej trzykrotnym zbiorem surowca frakcja modułów juwenilnych zmniejszyła się o połowę a generatywnych - nie pojawiła się. Skutkiem tego średni wiek modułów był wyższy niż w populacji nie zaburzanej. Wycinanie liści i kwiatostanów jest istotnym czynnikiem powstrzymującym rekrutację juwenilnych modułów. Rozrastanie się osobników spoczywało na modułach, które osiągnęły zdolność do pomnażania przed pojawieniem się zaburzenia. Mniejsza była frakcja osobników młodych (3-4 letnich), a dominowały osobniki 3-6 letnie.

SŁOWA KLUCZOWE: Convallaria majalis L., roślina lecznicza, struktura wiekowa, wycinanie pędów. 